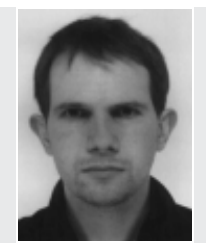
Michael J. Harbottle
Research Associate, Reparch Associate, Department of Engineering,
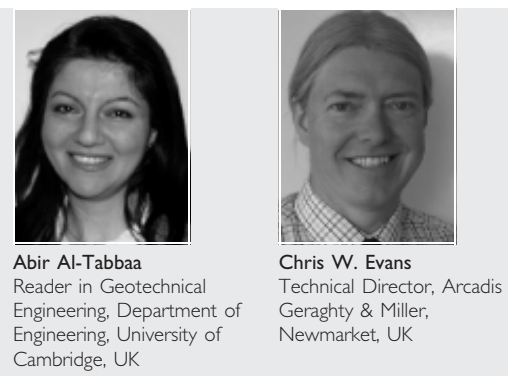

\title{
Sustainability of land remediation. Part 2: impact assessment
}

\author{
M. J. Harbottle DPhil, A. Al-Tabbaa PhD, CEng, MICE and C. W. Evans PhD, CEng, MICE
}

A comparative assessment was carried out of the technical/environmental sustainability of five different contaminated land remediation projects completed in the UK between 1997 and 2002 . The remediation technologies employed in those projects were in situ stabilisation/solidification, soil washing, ex situ bioremediation, cover system, and excavation and disposal to landfill. A further objective of the assessment was to highlight areas of sustainability concerns for the individual technologies and projects. The assessment is based around four principal criteria defined by the authors. Each project was assessed using both an overall multi-criteria analysis, detailed in Part I of this paper, and a detailed impact assessment, detailed here in Part 2.

\section{INTRODUCTION}

Part 1 of this publication ${ }^{1}$ presented an introduction to this twopart publication, including an overview of published work to date on the technical and environmental sustainability assessment of contaminated land remediation projects. It presented a sustainability assessment methodology based on four principal criteria. It then addressed the first of those criteria by assessing and comparing technical and environmental sustainability in terms of the costs and benefits of remediation using a detailed multi-criteria analysis (MCA) applied to five different remediation projects performed in the UK between 1997 and 2002. The technologies employed were in situ stabilisation/solidification, soil washing, ex situ bioremediation, cover system, and excavation and disposal to landfill. This paper, Part 2, presents and addresses the remaining three sustainability criteria, and concludes with a general discussion bringing together findings from both sets of analyses.

Full details of the five remediation projects were given in Part 1 , but a summary of their details is presented in Tables 1 and 2 and Fig. 1. The data presented are site-specific and therefore not necessarily representative of the remediation technique in general. Details of common parameters used in both analyses were provided in the Appendix to Part $1 .^{1}$

\section{ASSESSMENT OF TECHNICAL/ENVIRONMENTAL SUSTAINABILITY}

\section{I. Assessment criteria}

As outlined in Part $1,{ }^{1}$ a method for performing a sustainability assessment for technical and environmental aspects of contaminated land remediation projects has been presented based around four principal criteria.

(a) Criterion 1. Future benefits outweigh cost of remediation. This criterion was considered in detail in Part $1^{1}$ using a multi-criteria analysis.

(b) Criterion 2. The environmental impact of the remediation is less than the impact of leaving the land untreated. The environmental impacts of the 'remediation' and 'no action' options in terms of reducing or removing the risks of contamination to receptors should be measured and compared using factors such as future risk to human health, impact on ground conditions, impact on water flow, air pollution, flora and fauna, and restriction on future use of the land.

(c) Criterion 3. The environmental impact of bringing about the remediation process is minimal and measurable. This deals with the impact of bringing about the remediation process, rather than the effect of contamination, and includes impacts of all the processes involved, including transport, emissions to air, energy use, noise, waste and use of materials.

(d) Criterion 4. The timescale over which the environmental consequences occur, and hence inter-generational risk, is part of the decision-making process. Factors in this criterion include long-term monitoring and maintenance, post-closure maintenance, durability, future underground activities, land management issues, long-term contaminant degradation and sustainable use of the soil.

Criteria 2, 3 and 4 are addressed in detail in this paper using a detailed impact assessment.

\subsection{Assessment technique: detailed impact assessment (DIA)}

For the detailed impact assessment (DIA), comprehensive information on a number of different subcategories represented by criteria 2 to 4 above was collated and processed. In order to assess the whole life cycle of remediation, this included not just impacts due to the immediate remediation processes but also secondary effects such as transportation, production and extraction of raw materials and long-term effects. However, consideration of the use of materials is limited to consumables, such as fill and oil, and does not include materials used to build roads or machinery. As there is a very large number of individual impacts that could be considered, performing a DIA 
Project Details

Soil washing This contaminated former gasworks site was treated using a soil washing procedure for removing fine-grained soil constituents and the organic contamination contained therein. Remediation allowed redevelopment for commercial use, as well as protecting a river and groundwater supplies. Cleaned, coarse-grained soil was reused on site. This significantly reduced the amount of material disposed of in landfill, in turn reducing local disturbance through transportation.

Ex situ A range of former industries had left a number of organic contaminated areas on bioremediation this site, and so a combination of disposal to landfill (for very heavily contaminated soil) and bioremediation in windrows on the site itself was utilised. Bioremediated soil was reused on site. Potential receptors included a nearby river, groundwater supplies, and future site users on this mixed-use redevelopment.

Cover system The site had previously been a gasworks, resulting in a range of contaminants. This heavily contaminated site was remediated through hotspot excavation and off-site disposal followed by application of a cover, using recycled material where possible. The site was developed for commercial reuse. Further impact on groundwater was to be avoided, although specific treatment was not performed owing to the generally degraded nature of the local area.

Excavation and Contaminated material containing both organic and inorganic pollutants was disposal to excavated and disposed of in landfill. Recycled material was used for backfill. The landfill site was then reused for light industrial purposes.

calculated for before and after remediation, and for each contaminant present, hence presenting the effect of the remediation strategy adopted. A number of contaminants have been added to the basic database in the CLEA software to allow full consideration of site contamination.

Typical results are presented in Fig. 2, which shows ADE/ ID values for the four worst risk contaminants before remediation and the four worst risk contaminants after remediation, which are not necessarily the same. These are presented for all five remediation projects and for the oral and inhalation pathways only. The groups of four contaminants are

is extremely difficult if every impact is to be considered-as was noted in many of the studies quoted in the introduction section of Part $1 .^{1}$ Major impacts from each project have been included in this study, however.

As in the multi-criteria analysis, the DIA uses a functional unit of 'per tonne of remediated soil'. The data are presented in a non-aggregated form so that individual subcategories (e.g. gaseous emissions) can be directly compared between sites. This allows the identification of areas where one technology might have a more significant effect than another in the specific impact areas being considered.

\section{RESULTS AND DISCUSSION}

\section{I. Criterion 2. The environmental impact of the remediation is less than the impact of leaving the land untreated}

This criterion assesses the success of remediation in reducing or removing the risks of contamination to receptors, including future risk to human health, impact on ground conditions, impact on water, air pollution and flora and fauna, and restriction on future use of the land. The DIA of the future risk to human health is presented here.

The change in risk to humans due to soil contamination was assessed using the UK's contaminated land exposure assessment (CLEA) model. ${ }^{3,4}$ It determines the expected impact of contaminants on humans based on inhalation, oral and dermal contact pathways. In most cases, the soil conditions could be adequately modelled with the standard soil types in the program. However, an additional soil type was added to represent a stabilised/solidified soil, based on a clayey soil with low permeability and high $\mathrm{pH}$. The risk is presented here as a ratio of average daily exposure (ADE) to index dose (ID) (or tolerable daily exposure (TDI), whichever is applicable for the contaminant being considered). The ADE/ID ratio was presented in alphabetical order. In remediation projects the objective is usually to reduce the risk of contaminants to or below the ID or TDI values: hence the ratio of ADE/ID after remediation would not be expected to exceed 1.0. However, Fig. 2 shows this not to be the case for some of the projects and some of the contaminants. The remediation objectives of all the projects were achieved, and hence the risk levels after remediation were at an acceptable level. Some of the values are higher than 1.0 because maximum contaminant levels found on the sites were used in the CLEA analysis presented here, rather than average values, and are assumed to be present at or near the ground surface. Hence the results of the analysis performed can be considered as worst-case scenarios for the sites in question. Also, it is the risk reduction that is being addressed in the sustainability assessment here rather than the absolute risk values. It should be noted that the results before remediation correspond to the scenario of leaving the land untreated.

The results in Fig. 2 highlight the following for each project.

(a) For the S/S project, the risk of the four worst contaminants due to oral intake did not change significantly after remediation, since the same level of contamination remained in the ground, albeit with a small degree of dilution. The concentrations were also acceptable, so there was no need to reduce them further. However, the risk due to inhalation changed significantly after remediation, such that the value of ADE/ID reduced by around tenfold. In this project there were only four main contaminants, and so these are the main risks before and after.

(b) For the soil washing project, for the oral intake pathway some reduction in risk due to benzo(a)pyrene was seen, whereas little change was seen in the risk due to cadmium and cyanide. However, the reduction in risk due to lead was substantial. Risk through inhalation was reduced, by a factor of approximately 10 for benzene, and to a lesser 


\begin{tabular}{|c|c|c|c|c|c|}
\hline & $\begin{array}{l}\text { Stabilisation/ } \\
\text { solidification }\end{array}$ & Soil washing & Ex situ bioremediation & Cover system & Landfilling \\
\hline $\begin{array}{l}\text { Major } \\
\text { contamination* } \\
\text { (maximum in } \mathrm{mg} / \mathrm{kg} \text { ) }\end{array}$ & $\begin{array}{l}\text { BTEX (xylene to } \\
\text { 5000); TPH (8000) }\end{array}$ & $\begin{array}{l}\text { PAH (I 300); TPH } \\
\text { (7000); lead (3400) }\end{array}$ & $\begin{array}{l}\text { TPH (37 000); PAH } \\
\text { (7600); PCB (39); } \\
\text { lead (1400) }\end{array}$ & $\begin{array}{l}\text { PAH (I 20 000); } \\
\text { lead (I I 000); } \\
\text { cyanide }(44000) \\
\text { mercury }(200)\end{array}$ & $\begin{array}{l}\text { TPH }(58000) ; \text { lead } \\
(61000) ; \\
\text { arsenic }(13000)\end{array}$ \\
\hline $\begin{array}{l}\text { Mass and fate of soil } \\
\text { remediated: }{ }^{\dagger} \mathrm{t}\end{array}$ & On-site reuse: 7040 & $\begin{array}{l}\text { Landfill: I08000; } \\
\text { off-site reuse: } \\
\text { II I00; on-site } \\
\text { reuse: I } 58000\end{array}$ & $\begin{array}{l}\text { Landfill: } 25700 \text {; } \\
\text { bioremediation/on-site } \\
\text { reuse: } 56700\end{array}$ & $\begin{array}{l}\text { Landfill: } 190000 \\
\text { on-site reuse: } 882000\end{array}$ & Landfill: 4680 \\
\hline $\begin{array}{l}\text { Fate of soil } \\
\text { remediated: \% }\end{array}$ & On-site reuse: 100 & $\begin{array}{l}\text { Landfill: } 39 \text {; off-site } \\
\text { reuse: } 4 \text {; on-site } \\
\text { reuse: } 57\end{array}$ & $\begin{array}{l}\text { Landfill: } 32 \text {; } \\
\text { bioremediation/on-site } \\
\text { reuse: } 68\end{array}$ & $\begin{array}{l}\text { Landfill: I3; on-site } \\
\text { reuse: } 87\end{array}$ & Landfill: 100 \\
\hline $\begin{array}{l}\text { Soil organic matter: } \\
\%\end{array}$ & 2 & $\begin{array}{l}2(15.5 \text { in waste } \\
\text { fines) }\end{array}$ & $2^{\mathbf{\sigma}}$ & $2^{\pi}$ & 17 \\
\hline $\begin{array}{l}\text { Materials used in } \\
\text { remediation: } \\
\mathrm{kg} / \mathrm{t} \text { soil }\end{array}$ & $\begin{array}{l}\text { Cement: } * 43 ; \\
\text { bentonite: } 17\end{array}$ & Clean fill: 293 & $\begin{array}{l}\text { Nutrients } \\
\text { Clean fill: } 318\end{array}$ & $\begin{array}{l}\text { Geomembrane } \\
\text { Recycled fill: } 317\end{array}$ & Recycled fill: 1000 \\
\hline Water use & $\begin{array}{l}227 \mathrm{~kg} / \mathrm{t} \text { soil } \\
\text { remediated }\end{array}$ & $\begin{array}{l}112 \mathrm{~kg} / \mathrm{t} \text { soil } \\
\text { remediated }\end{array}$ & $\begin{array}{l}\text { Up to } 10 \mathrm{~m}^{3} \text { per day } \\
\text { per windrow }\end{array}$ & N/A & $\begin{array}{l}1.9 \mathrm{~kg} / \mathrm{t} \text { soil } \\
\text { remediated }\end{array}$ \\
\hline $\begin{array}{l}\text { Distance to material } \\
\text { supply or disposal } \\
\text { site: } \mathrm{km}\end{array}$ & $\begin{array}{l}\text { Bentonite: } 88 \text {; } \\
\text { cement: } 24\end{array}$ & $\begin{array}{l}\text { Borrow pit: } 24 \\
\text { landfill: } 8\end{array}$ & $\begin{array}{l}\text { Borrow pit: } 20 ; \\
\text { landfill: } 312 \text { (by rail) }\end{array}$ & $\begin{array}{l}\text { Borrow pit: I; landfill: } \\
\text { several landfills used }\end{array}$ & $\begin{array}{l}\text { Borrow pit: } 0 ; \\
\text { (stockpiles on site); } \\
\text { landfill: } 12\end{array}$ \\
\hline Site plant used & $\begin{array}{l}2 \text { auger rigs }+ \\
\text { batching plant }\end{array}$ & $\begin{array}{l}4 \text { excavators, } 4 \\
\text { bulldozers/ } \\
\text { compactors, } 2 \\
\text { loaders, crusher, } 2 \\
\text { screens, soil washing } \\
\text { unit }^{\text {I }}\end{array}$ & $\begin{array}{l}4 \text { excavators, } 4 \\
\text { bulldozers/compactors, } \\
4 \text { loaders, windrow } \\
\text { turner, } 2 \text { screens, } \\
\text { crusher }\end{array}$ & $\begin{array}{l}5 \text { excavators, } 4 \\
\text {, loaders, crusher, } 3 \\
\text { screens, } 5 \text { bulldozers/ } \\
\text { compactors }\end{array}$ & $\begin{array}{l}2 \text { excavators, } 2 \\
\text { bulldozers/ } \\
\text { compactors }\end{array}$ \\
\hline $\begin{array}{l}\text { Distance from plant } \\
\text { supply: km }\end{array}$ & 104 & 91 & 34 & 332 & 332 \\
\hline $\begin{array}{l}\text { Energy requirement } \\
\text { (other than vehicle } \\
\text { fuel) }\end{array}$ & $\begin{array}{l}0.154 \mathrm{~kg} \mathrm{coal} / \mathrm{kg} \\
\text { cement, electricity } \\
\text { (clinker grinding) - } \\
30 \mathrm{kWh} / \mathrm{t}^{\S}\end{array}$ & $\begin{array}{l}1.29 \mathrm{kWh} / \mathrm{t} \\
\text { electricity (assumed } \\
100 \mathrm{~kW} \text { soil washing } \\
\text { unit) }\end{array}$ & None considered & None considered & None considered \\
\hline $\begin{array}{l}\text { Duration of } \\
\text { treatment: months }\end{array}$ & 2 & 16 & 11 & 13 & 2 \\
\hline
\end{tabular}

*BTEX: benzene, toluene, ethylbenzene, xylene; TPH: total petroleum hydrocarbons; PAH: polycyclic aromatic hydrocarbons; PCB: polychlorinated biphenyls.

tWhere volume only was known, converted to mass using assumed density of $1.6 \mathrm{t} / \mathrm{m}^{3}$.

Per t cement: $1.10 \mathrm{t}$ limestone, $0.34 \mathrm{t}$ shale, $0.06 \mathrm{t}$ sand, $5 \mathrm{~kg}$ iron oxide. ${ }^{2}$

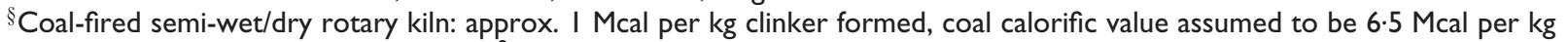
(assumed all clinker ground to cement). ${ }^{2}$

ivalue assumed.

Table 2. Summary of relevant data for remediation projects considered

degree for lead, naphthalene and xylene. The major impact of the soil washing remediation was therefore on the organic compounds.

(c) For the ex situ bioremediation project, benzene and naphthalene-two of the main oral intake risk contaminants prior to remediation-were not among the worst after remediation, with significant reductions by factors of $10-$ 100. The risk due to more persistent contaminants, such as polychlorinated biphenyls, was also reduced by a factor of 10. Through inhalation many of the worst risk contaminants are the same, with significant reduction in risk for the organic contaminants. In this project the target contaminants were organics, and hence the concentration of the heavy metals following remediation was not measured and so was assumed to have remained the same. Lead was the worst risk heavy metal contaminant.

(d) For both the oral and inhalation routes in the cover system project, the risk due to volatile contaminants such as benzo(a)pyrene and PAHs (e.g. naphthalene) was significantly reduced, by up to a factor of 500, while the reduction of the risk due to metals was less, by up to a factor of 10 .

(e) For the excavation and disposal to landfill project, the four worst contaminants in both the oral and inhalation routes, and both before and after treatment (after treatment refers to the contaminants remaining on the site itself), were all inorganic. The reduction in the risk due to these contaminants following treatment was reduced by a factor of $10-1000$. The risk due to cyanide was reduced by very little for the oral route, whereas it was reduced to some degree for the inhalation route.

Following the individual risk assessment of each remediation project, the maximum $\mathrm{ADE} / \mathrm{ID}$ value after remediation was divided by the maximum value before remediation, both shown in Fig. 2, to give an indication of the maximum risk reduction for each project. The results are presented in Fig. 3 as a percentage: they indicate at least 97\% maximum risk reduction 

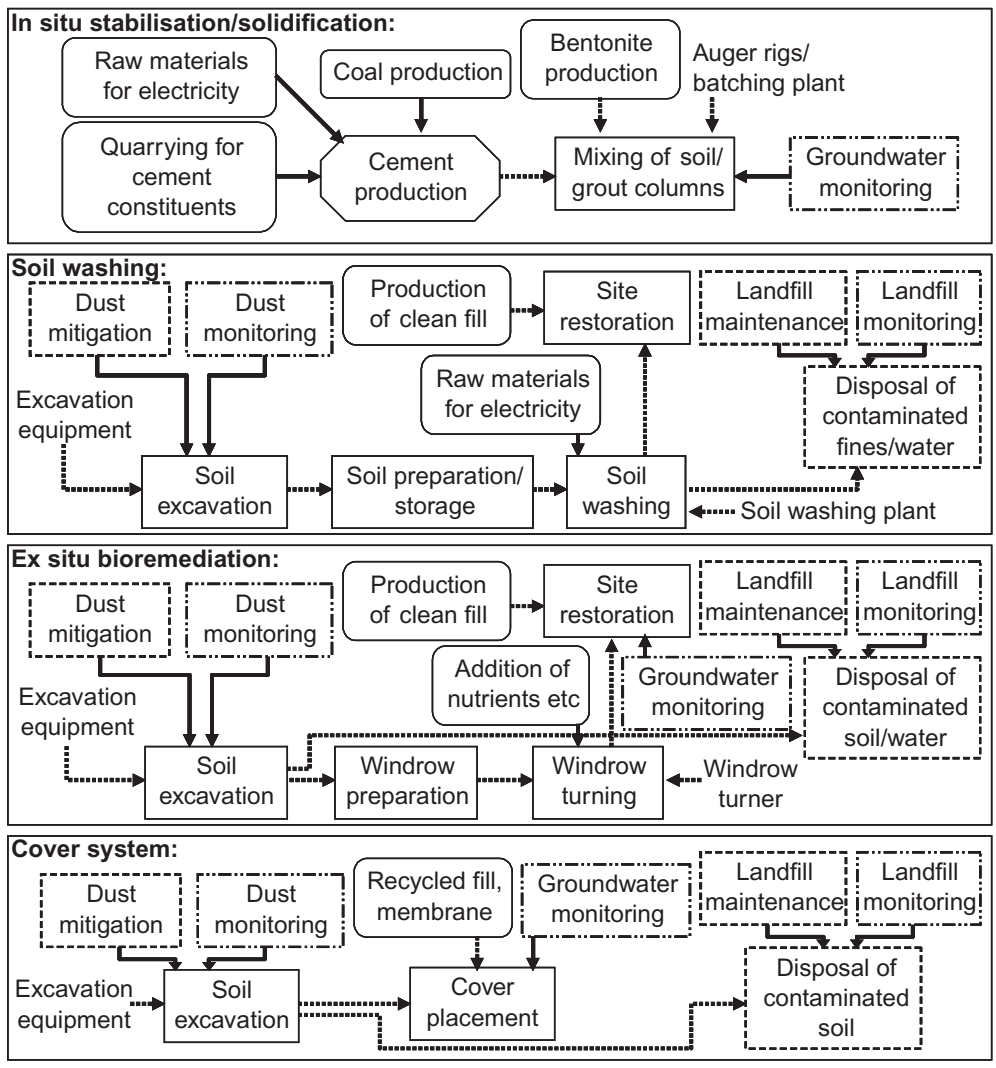

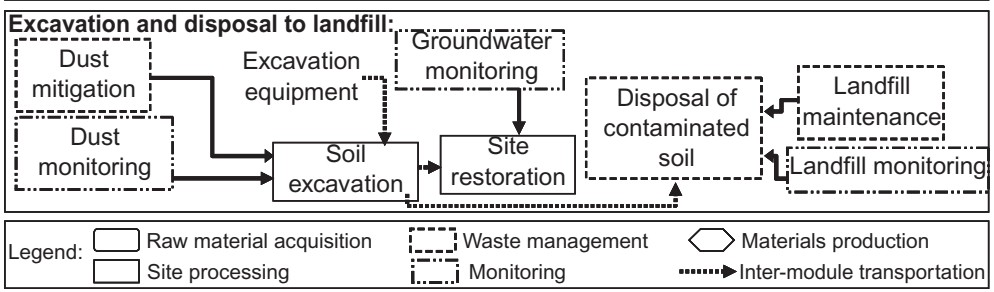

Fig. I. Flow diagrams for the five remediation projects, showing major remediation stages and inputs

in all projects, that value being for the in situ S/S project and over 99\% for the ex situ bioremediation project. Hence, according to CLEA, all five projects significantly reduced the risk of contamination compared with a no-action scenario. One of the reasons for the very large reduction in risk for the ex situ bioremediation and cover systems was the initial very high concentrations of some contaminants present on those sites.

\subsection{Criterion 3. The environmental impact of bringing about the remediation process is minimal and measurable}

The implementation of remediation techniques will create impacts entirely separate and different from those due to the contamination on the site. These include the impacts of all the processes involved including transport, emissions to air, energy use, noise, waste and use of natural resources.

Emissions to air for each of the five remediation projects are given in the top half of Table 3 , in $\mathrm{kg} / \mathrm{t}$ of soil remediated. Emissions during the remediation process were calculated from the sources listed in the Appendix in Part $1,{ }^{1}$ and those after remediation were mainly linked to the landfilling part of the projects. Table 3 clearly shows that by far the largest actual emissions are those of $\mathrm{CO}_{2}$ during the remediation process, and this value is relatively very high in the in situ S/S project, primarily because of cement manufacture. This is slightly offset by subsequent absorption over time, through carbonation (taken as $0 \cdot 1 \mathrm{~kg}$ $\mathrm{CO}_{2} / \mathrm{kg}$ cement)-hence the negative sign for $\mathrm{CO}_{2}$ emission after remediation. In the remaining projects the negative emission values after remediation arise because methane production in the landfill was considered to be 'lost' $\mathrm{CO}_{2}$ that would otherwise have been emitted. For substances other than $\mathrm{CO}_{2}$, trends exist in the emissions produced.

Typically, the cover system project produced the lowest emissions for all chemical species studied. S/S and soil washing were typically very similar, while those for bioremediation were slightly less and those for landfilling slightly more.

In order to enable a simple comparison to be made of the emissions between the different remediation projects, the emissions data have been factored and combined to give values in a number of impact areas, such as global warming potential and acidification potential. These have been calculated using the US BEES analysis method, ${ }^{5}$ and are presented in the bottom half of Table 3. These were then normalised and weighted to allow direct impact comparisons, and the results are shown in Fig. 4. Further details on this stage can be found in the Appendix to Part $1 .{ }^{1}$ Table 3 and Fig. 4 show that trends visible in the raw data do not necessarily correspond to those after combination. The global warming potential was significantly higher in the $S / S$ project than in any other, but there was little variation for acidification or eutrophication potentials, human health, ecological toxicity or smog. Impacts on human health from emissions were considerably lower than from the majority of other impact areas. Smog and ecological toxicity had the highest impact over all categories in each case, primarily because of the level of contribution of non-methane volatile organic compound emissions in the former and carbon monoxide emission in the latter. By summing the normalised and weighted impacts it was found that, overall, the cover system project had the lowest impact due to total emissions and the landfilling project the highest. 

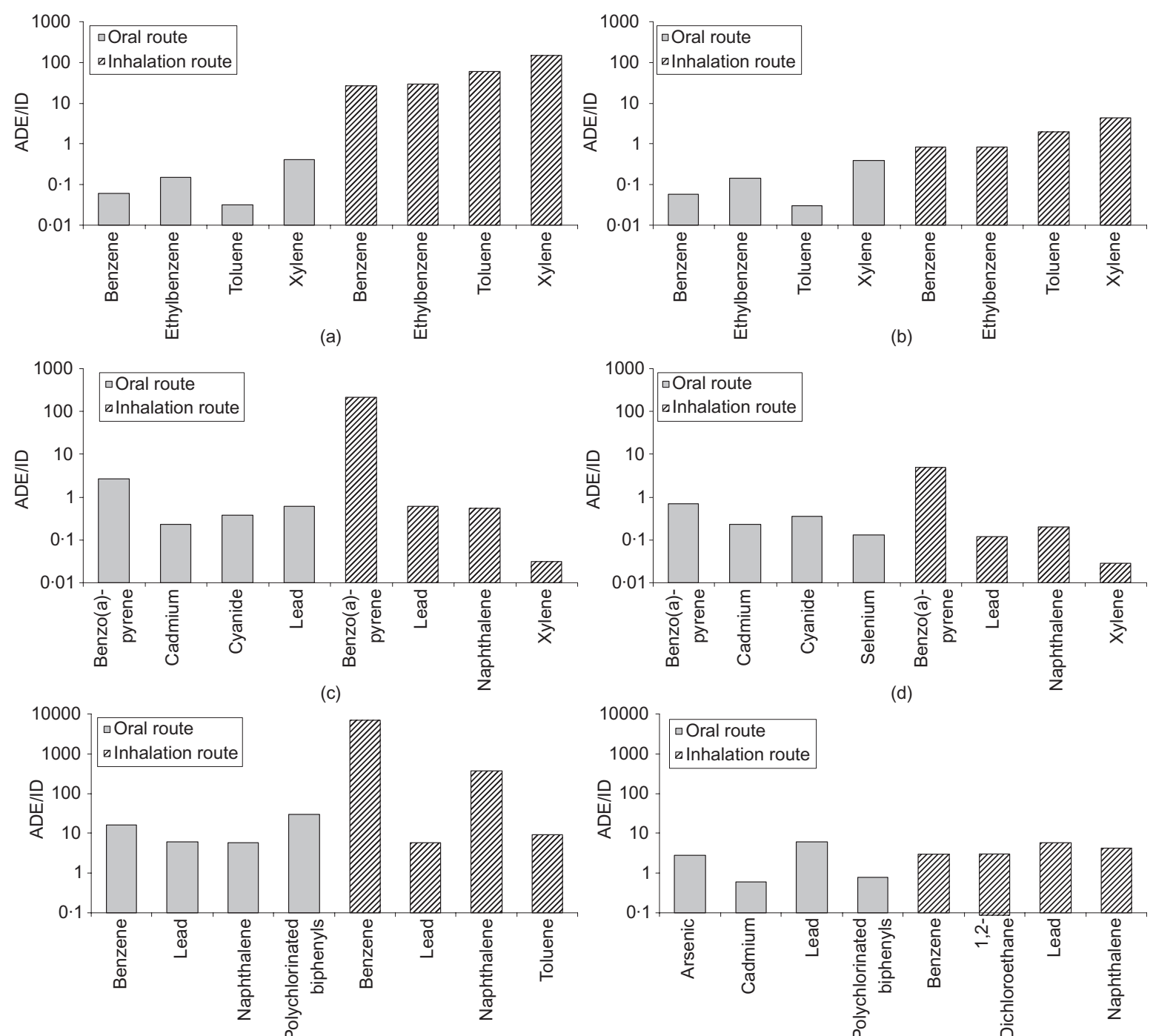

(d)
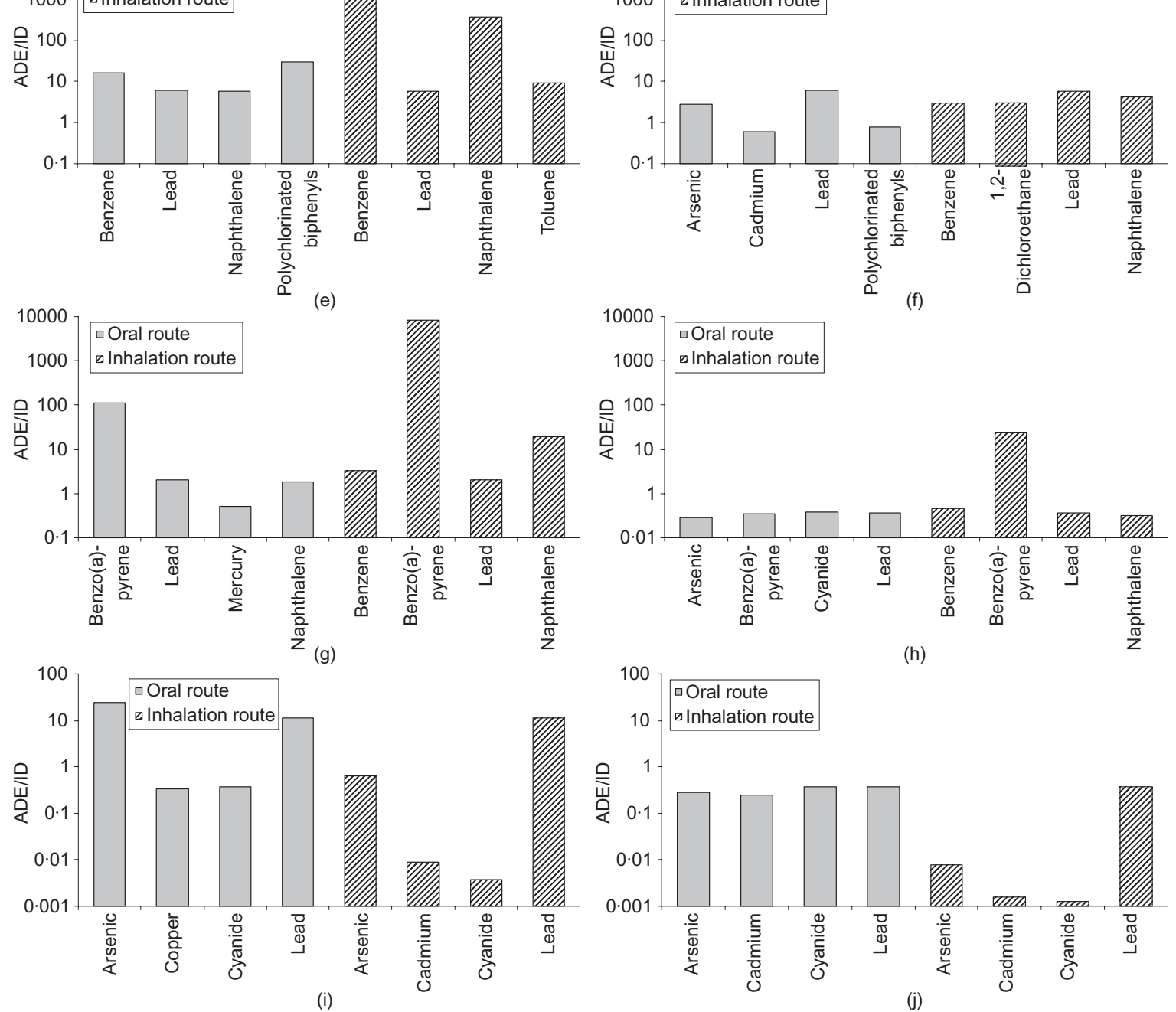


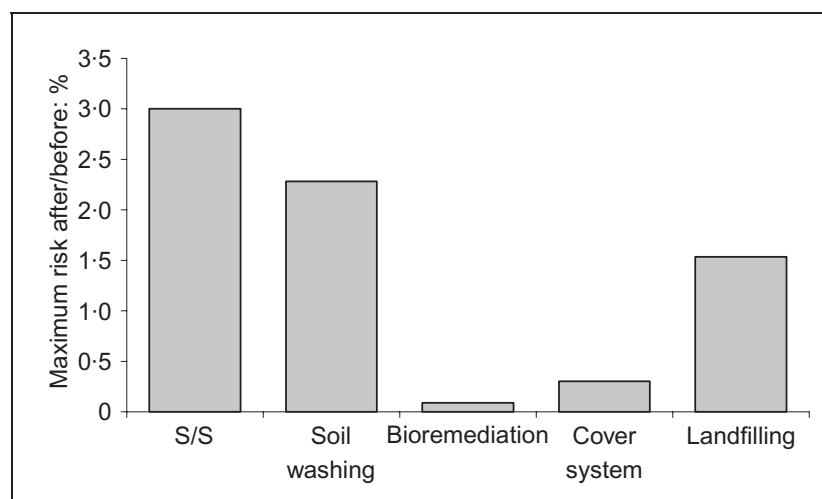

Fig. 3. Maximum risk ratio for the five remediation projects, as determined using CLEA

Transportation has a number of consequences other than emissions, such as disturbance and congestion. It is represented here in Fig. 5 through the mileage travelled on different road categories, namely motorways, main roads (A roads) and local roads, since each has different costs and benefits. Road travel in this study is linked mainly to delivery of raw material and removal of waste to landfill. The total road travel varied from 0.5 to $3.5 \mathrm{~km} / \mathrm{t}$ soil remediated, the smallest value being for the $\mathrm{S} / \mathrm{S}$ project and the largest for the disposal to landfill project. It is no surprise that the latter project had the highest calculated distance of travel. Both the cover system and soil washing projects also involved some degree of material import and export. The use of rail transport for waste material in the ex

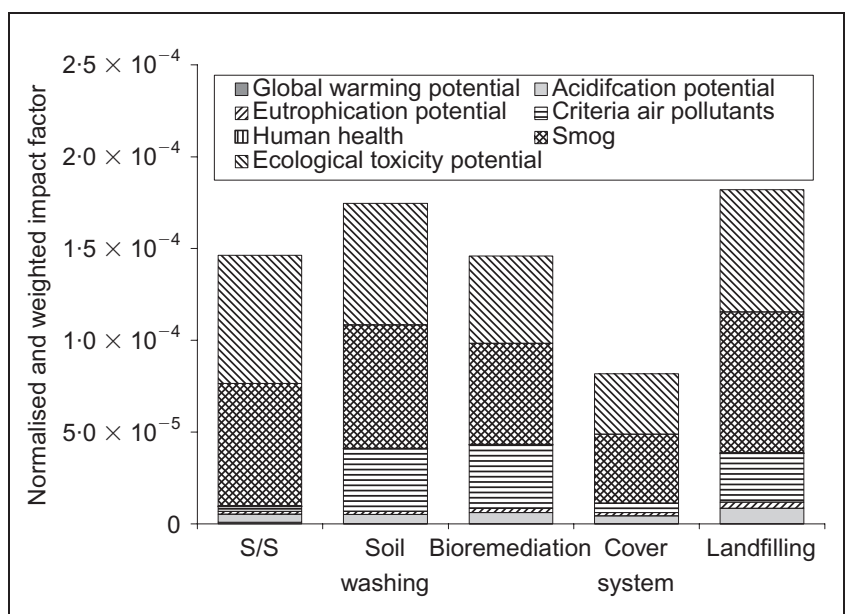

Fig. 4. Normalised and weighted impact factors comparing effects of emissions from the different remediation projects

situ bioremediation project considerably reduced the need for road travel, while the nature of S/S minimised off-site transportation, with all movements being due to raw material supply. Other impacts from road use, for example congestion and accidents, which both have an economic and societal cost, have not been considered here.

Table 4 shows the materials used in each remediation project. Small quantities of materials were used in the S/S and soil washing projects for cement production and electricity generation. The dominant material use was of fill, and hence

\begin{tabular}{|c|c|c|c|c|c|}
\hline & $\mathrm{S} / \mathrm{S}$ & Soil washing & Bioremediation & Cover system & Landfilling \\
\hline $\mathrm{CO}_{2}$ during & 150 & 14 & 16 & 8.9 & 17 \\
\hline $\mathrm{CO}_{2}$ after & $-4 \cdot 3$ & -0.076 & -0.0077 & -0.0031 & -0.21 \\
\hline $\mathrm{CH}_{4}$ during & 0.0074 & 0.0052 & 0.0038 & 0.0026 & 0.0055 \\
\hline $\mathrm{CH}_{4}$ after & 0 & 0.028 & 0.0028 & 0.0011 & 0.076 \\
\hline $\mathrm{N}_{2} \mathrm{O}$ & 0.00074 & 0.0001 & 0.00084 & 0.000081 & 0.00016 \\
\hline $\mathrm{CO}$ & $2 \cdot 1$ & $2 \cdot 0$ & $1 \cdot 5$ & 1.0 & $2 \cdot 0$ \\
\hline $\mathrm{NO}_{x}$ & 0.013 & 0.016 & 0.021 & 0.017 & 0.032 \\
\hline $\mathrm{SO}_{2}$ & 0.0034 & 0.0034 & 0.0019 & $0.000 \mathrm{II}$ & 0.00022 \\
\hline NMVOC & 0.11 & 0.11 & 0.080 & 0.055 & 0.11 \\
\hline Benzene & 0.0077 & 0.0073 & 0.0052 & 0.0036 & 0.0073 \\
\hline I,3-butadiene & 0.0016 & 0.0016 & 0.0013 & 0.00081 & 0.0017 \\
\hline PMIO & 0.0010 & 0.13 & 0.13 & 0.020 & 0.10 \\
\hline Black smoke & 0.0072 & 0.00059 & 0.00088 & 0.00027 & 0.00055 \\
\hline Mercury & $5.3 \times 10^{-9}$ & $5.3 \times 10^{-9}$ & $6.5 \times 10^{-11}$ & 0 & 0 \\
\hline Lead & $9.1 \times 10^{-7}$ & $8.7 \times 10^{-7}$ & $7 \cdot 1 \times 10^{-7}$ & $4.0 \times 10^{-7}$ & $8.0 \times 10^{-7}$ \\
\hline Benzo(a)pyrene & $2.6 \times 10^{-8}$ & $2.5 \times 10^{-8}$ & $1.8 \times 10^{-8}$ & $1.2 \times 10^{-8}$ & $2.5 \times 10^{-8}$ \\
\hline Global warming potential* & $145 \cdot 9$ & $14 \cdot 5$ & 16.4 & $9 \cdot 0$ & $19 \cdot 1$ \\
\hline Acidification potential $^{\dagger}$ & 0.68 & 0.79 & 0.93 & 0.66 & $1 \cdot 29$ \\
\hline Eutrophication potential & 0.00058 & 0.00063 & 0.00091 & 0.00067 & 0.00129 \\
\hline Criteria air pollutants $\S$ & 0.9 & 10.9 & $\mid 1 \cdot 1$ & $1 \cdot 7$ & $8 \cdot 5$ \\
\hline Human health & $1.6 \mid$ & 1.53 & $1 \cdot 16$ & 0.66 & $1 \cdot 34$ \\
\hline Smog $^{+}$ & 0.17 & 0.17 & 0.14 & 0.095 & 0.19 \\
\hline Ecological toxicity potential ${ }^{\#}$ & 0.052 & 0.049 & 0.035 & 0.024 & 0.049 \\
\hline
\end{tabular}

*kg CO 2 equivalent (includes $\mathrm{CO}_{2}, \mathrm{CH}_{4}$ and $\mathrm{N}_{2} \mathrm{O}$ ).

${ }^{\dagger} \mathrm{kg} \mathrm{H}{ }^{+}$equivalents (includes $\mathrm{NO}_{\times}$and $\mathrm{SO}_{2}$ ).

${ }^{*} \mathrm{~kg} \mathrm{~N}$ equivalents (includes $\mathrm{NO}_{x}$ and $\mathrm{N}_{2} \mathrm{O}$ ).

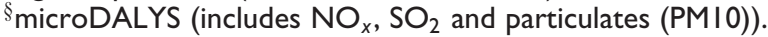

${ }^{\top} \mathrm{kg}$ toluene equivalent (includes $\mathrm{SO}_{2}$, benzene, I,3-butadiene, mercury and lead).

${ }^{+} \mathrm{kg}$ nitrogen oxides equivalents (includes $\mathrm{CH}_{4}, \mathrm{CO}, \mathrm{NMVOC}$, benzene, PMIO, benzo(a)pyrene $\mathrm{NO}_{x}$ and I,3-butadiene).

${ }^{\#} \mathrm{~kg}$ 2,4-dichlorophenoxyacetic acid equivalents (includes $\mathrm{N}_{2} \mathrm{O}, \mathrm{NO}_{x}, \mathrm{CO}, \mathrm{NMVOC}$, benzene, mercury, lead and benzo(a)pyrene). 


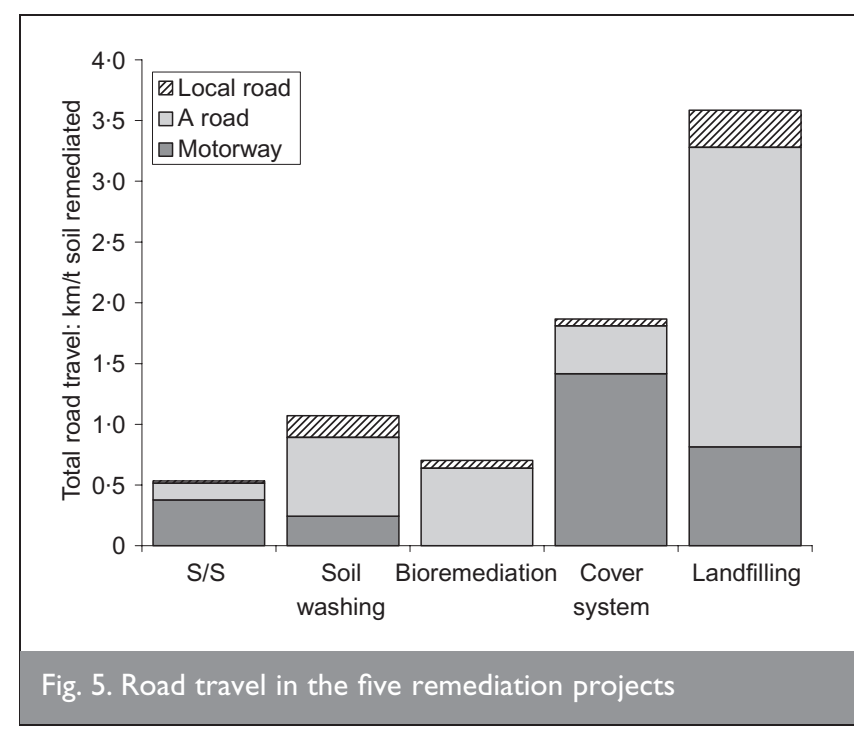

the use of recycled material, or performing the remediation in situ, could significantly reduce the requirement for virgin material, as was the case with the landfilling and cover system projects. Although the S/S project used a variety of different materials, overall raw material use was not as high. Because of a lack of actual information, soil washing and bioremediation were presumed to use virgin fill, and had the highest use of raw materials. The results in Table 4 are displayed in Fig. 6, grouped under the headings of recycled (site soil), other recycled and raw materials. The results show that the projects used between 1 and $1.4 \mathrm{t}$ of material per tonne of remediated soil (including reused site soil), the least quantity being for the landfilling project and the largest for the in situ S/S project.

If the projects are compared in terms of total materials imported (least sustainable option) or amount of site soil recycled (most sustainable option), then the landfilling project performed the worst and the in situ S/S project the best.

The effect on future usability of all the project sites was determined based on six different categories of potential future use, namely green space, agricultural, residential, commercial, industrial and non-green open space. The change in the number of potential future uses due to remediation was

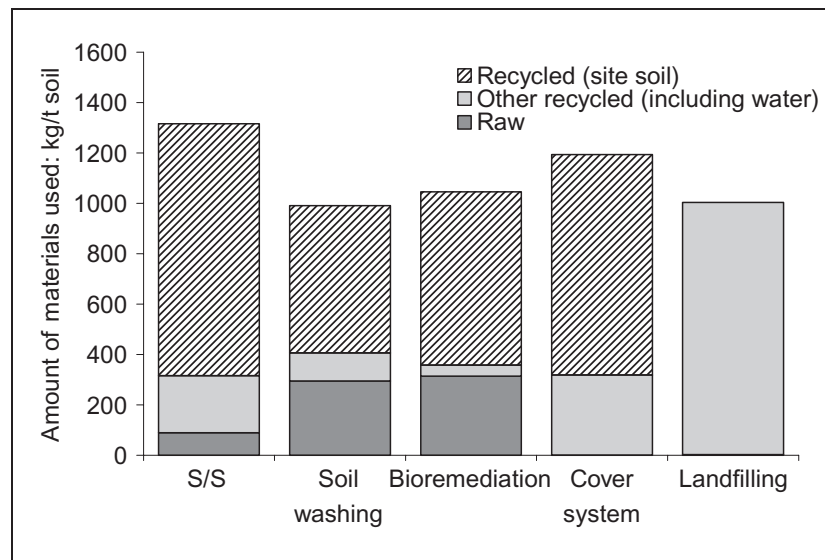

Fig. 6. Total recycled and raw materials used in the five remediation projects.

determined for the remediated site itself, the landfill and quarry or borrow pit used, and then summed, after normalisation by the quantity of soil/excavated material for each site. The site was initially assumed to have no potential future uses because of the contamination. Waste was assumed to be disposed of in a landfill (such as a former quarry), which would otherwise not be usable in any of the six categories. Following remediation, possible uses included green and non-green open space. A borrow pit would initially be assumed to be pristine (all six categories possible), but following the remediation process (i.e. the extraction of material) this would be reduced to zero. Table 5 lists the resulting scores for future site usability: each score is the number of uses the site could potentially have postremediation. For ancillary sites, scores are proportional to their involvement in the project. Both $\mathrm{S} / \mathrm{S}$ and bioremediation sites were redeveloped for residential purposes, and so could conceivably be used for many other uses, whereas the other sites were developed for commercial or industrial use and so had a higher contamination risk. The results in Table 5 show that the excavation and disposal to landfill and S/S project scored the highest, while soil washing scored the lowest. The excavation and disposal project employed recycled fill, removing any effect due to borrow pits, and so gained a high score despite redevelopment to commercial/industrial standards only. S/S had no impact off site other than in sourcing raw

\begin{tabular}{|c|c|c|c|c|c|c|}
\hline Material & Use & $S / S$ & Soil washing & Bioremediation & Cover system & Landfilling \\
\hline Limestone & Cement & $46 \cdot 7$ & 0 & 0 & 0 & 0 \\
\hline Shale & Cement & 14.4 & 0 & 0 & 0 & 0 \\
\hline Sand & Cement & $2 \cdot 68$ & 0 & 0 & 0 & 0 \\
\hline Iron oxide & Cement & 0.192 & 0 & 0 & 0 & 0 \\
\hline Bentonite & S/S binder & $17 \cdot 1$ & 0 & 0 & 0 & 0 \\
\hline Coal & Electricity/cement & $6 \cdot 73$ & 0.175 & 0 & 0 & 0 \\
\hline Natural gas & Electricity & 0.122 & 0.124 & 0 & 0 & 0 \\
\hline Uranium ore & Electricity & 0.0222 & 0.022 & 0 & 0 & 0 \\
\hline Crude oil & Various & 1.07 & $1 \cdot 18$ & 1.48 & 1.00 & 1.96 \\
\hline Water & Various & 227 & 112 & $44 \cdot 3$ & 0 & 1.94 \\
\hline Virgin fill & Fill & 0 & 293 & 306 & 0 & 0 \\
\hline Recycled fill & Fill & 0 & 0 & 0 & 317 & 1000 \\
\hline Recycled site soil & Fill & 1000 & 585 & 688 & 875 & 0 \\
\hline Total & & 1316 & 991 & 1046 & 1194 & 1004 \\
\hline
\end{tabular}




\begin{tabular}{|lccccc|}
\hline & S/S & Soil washing & Bioremediation & Cover system & Landfilling \\
\hline On site & 5 & 3 & 5 & 3 & 3 \\
Quarry/borrow pit & -0.5 & -1.8 & -1.9 & 0 & 0 \\
On landfill & 0 & 0.8 & 0.6 & 0.2 & 2 \\
Total score & 4.5 & 2.0 & 3.7 & $3 \cdot 2$ & 5.0 \\
& & & & & \\
\hline
\end{tabular}

project was particularly low thanks to the use of rail in waste disposal.

(d) Impact on other sites. This was quantified by the total quantity of material extracted (raw materials) or dumped off site (waste). The S/S project had a low impact

materials, and was remediated to a residential standard. The soil washing project was remediated to commercial/industrial standard, and also sourced virgin material from a borrow pit.

Additional comparisons included in this analysis are discussed below, with the comparative results presented in Table 6 .

(a) Energy use. The energy used is tabulated in terms of both electricity use and use of oil (typical value $12 \mathrm{kWh} / \mathrm{kg}$, using crude oil data from Table 4). Electricity was mainly used in the S/S and soil washing projects, for cement production and plant operation respectively, whereas oil was used throughout all projects, for equipment, for transportation, and also as a component in electricity generation. Where electricity was used as part of the remediation project it was only a small part of the total energy requirement ( $\sim 10 \%)$. Energy use was highest for the excavation and disposal to landfill project, and lowest for the cover system project.

(b) Noise. The extent of noise during remediation operations was estimated as described in the Appendix to Part $1 .{ }^{1}$ Soil washing, bioremediation and cover system projects used a mobile crusher, and were considerably noisier than the S/S and landfilling projects. S/S was a particularly quiet process, with minimal site noise.

(c) Disturbance to the local area. This was quantified in terms of the number of HGV movements and length of the site work duration. Table 6 shows that S/S and excavation and disposal to landfill, the two smallest projects, had a long duration. The latter also had the highest number of HGV movements by far. The largerscale projects (soil washing, bioremediation and cover system) had a relatively low HGV movement concentration, and also a shorter duration per t of soil remediated. HGV movement for the bioremediation under these terms, as did the cover system project, owing to low waste generation and material use. The landfilling project performed worst, because the contaminated soil was all disposed off site.

(e) Remediation location. This considered whether the process took place in situ (a score of 3), on site ex situ (a score of 2) or off site (a score of 1), with the score indicating increasing order of preference. Most of the projects involved more than one remediation method, and so the overall score for this measure was determined by adding the scores for the proportions of soil treated in different places. S/S was performed entirely on site and so had the highest score. The cover system was also largely an in situ procedure and scored highly. Soil washing and ex situ bioremediation involved extensive excavation, which reduced their score.

( $f$ ) Break in pollutant linkage. This used a similar method to scoring remediation location, with source treatment given a score of 3, pathway a score of 2 and receptor a score of 1 , as removing the source is unlikely to require further work if circumstances change. Again, most of the projects involved more than one aspect of the pollutant linkage, and so the overall score was determined by adding the scores for the proportions of soil treated in the different pollutant linkages aspects. Only bioremediation involved any form of source destruction; in all the other projects the pathway was broken but contaminants remained after remediation.

\subsection{Criterion 4. The timescale over which the environmental consequences occur, and hence intergenerational risk, is part of the decision-making process}

This criterion considers the impacts of factors such as longterm monitoring and maintenance, durability, long-term

\begin{tabular}{|c|c|c|c|c|c|c|}
\hline & & $S / S$ & Soil washing & Bioremediation & Cover system & Landfilling \\
\hline \multirow[t]{2}{*}{ Energy use: $\mathrm{kWh} / \mathrm{t}$ soil } & Electricity & $1 \cdot 3$ & $1 \cdot 3$ & 0 & 0 & 0 \\
\hline & Crude oil & $12 \cdot 8$ & $14 \cdot 2$ & $17 \cdot 8$ & $12 \cdot 0$ & $23 \cdot 5$ \\
\hline \multicolumn{2}{|c|}{ Noise: $\mathrm{dB}(\mathrm{A})$} & 61.5 & 76 & 77 & 78 & 69 \\
\hline \multicolumn{2}{|c|}{$\begin{array}{l}\text { HGV movements: } \times 10^{-3} \text { per month/t soil } \\
\text { remediated) }\end{array}$} & 3.6 & $4 \cdot 6$ & $2 \cdot 9$ & $3 \cdot 4$ & 51 \\
\hline \multicolumn{2}{|c|}{$\begin{array}{l}\text { Length of site works: } \times 10^{-5} \text { months } / \mathrm{t} \text { soil } \\
\text { remediated) }\end{array}$} & 28 & $5 \cdot 8$ & 14 & $1 \cdot 3$ & 43 \\
\hline Impact on other sites: & Raw material & 89 & 295 & 313 & I & 2 \\
\hline (kg/t soil remediated) & Waste & 0 & 400 & 312 & 125 & 1000 \\
\hline Remediation location & & 3 & 1.6 & 1.7 & $2 \cdot 7$ & 1 \\
\hline Break in pollutant linkage & & 2 & 2 & $2 \cdot 7$ & 2 & 2 \\
\hline
\end{tabular}


contaminant degradation, future underground activities, land management issues and the sustainable use of the soil. Many of these factors are not usually considered in any assessment of the impact of remediation projects, and many of the data are not usually easily available and are site-specific. Also, many of these aspects require consideration over a long period of time after the completion of the remediation project.

One area that has received some research attention in recent years is the durability of remediation techniques, and this therefore could be used to speculate on the impacts on the five projects considered here. It includes the physical durability of containment systems, the longevity of the remediation process, and aspects of long-term contaminant degradation. In all five remediation projects considered, at least part, and in some cases all, of the contamination remained within the site soil in its original form, although the soil may have been moved elsewhere. Therefore, although the risks from the contamination are suitably low following remediation, there is the potential for risks to arise in the future, if the containment system employed breaks down, or conditions change to affect the risk associated with the contamination on site. In addition, this residual level of contamination could restrict future redevelopment of the site for other uses.

In most of the projects there was a degree of monitoring of the groundwater, and in some cases gaseous emissions, on the remediated site for up to two years following remediation. The limited period of this monitoring was related mainly to regulatory requirements, and its purpose was to ensure that the remediation system employed was operating as expected. There is currently no requirement to monitor the site continuously beyond this. This indicates that there is an implicit assumption that any containment system put in place will continue to work in the future as designed, or the risk of residual contamination levels will not change. Aftercare on site, unless originally designed as part of the decision-making process, is usually likely to be difficult or impractical owing to site and use constraints.

Durability is a commonly voiced concern with in situ S/S as contaminant immobilisation takes place on site. Recent work performed on the medium-term performance of in situ S/S systems suggests satisfactory performance, with no significant deterioration of the stabilised/solidified mass, up to 15 years after treatment. ${ }^{6,7}$ Potential degradation mechanisms that may in the long-term cause an S/S system to break down have been documented, ${ }^{8}$ and these need to be addressed when specifying $\mathrm{S} / \mathrm{S}$ as a remediation technique if the technical/environmental sustainability is taken on board.

In the cover system project the cover consisted of granular material overlying a geomembrane. Considerable work has been performed on the long-term performance of cover systems. However, all studies to date have concentrated on the performance of compacted clay covers, with problems such as desiccation and cracking reported. ${ }^{9}$ It is apparent that this is the dominant form of cover system failure, as it allows infiltration of rainwater into the protected area, and so it is this that would have to be considered when assessing the full performance of such a barrier. In the current work, however, the major problem in the long term is likely to be the potential of future development breaching this cover.
The soil washing, cover system and excavation and disposal to landfill projects involved the majority of the contaminants being disposed of in landfill while leaving some soil with lowlevel contamination in place, as it was not practical or economical to remove it. Soil washing and excavation and disposal to landfill projects generally do not have any additional measures put in place to contain residual contaminants. However, well-engineered cover systems usually do, in the form of various levels of protection such as marker geotextiles, capillary break layers and impermeable clay layers. This form of protection is for receptors at ground level, and hence other receptors such as groundwater could potentially be affected in the future should conditions change.

Bioremediation has the distinct relative advantage that the majority of organic contamination not disposed of in landfill would be destroyed or transformed, but again low levels of contamination as well as any inorganic contaminants not disposed of in landfill would remain on site. In the long term these might be subject to some form of natural attenuation, ${ }^{10}$ or might be affected by natural or man-made processes that increased their availability to receptors, for example rising groundwater levels. ${ }^{11}$

The landfills in which the contaminated material from the projects considered was disposed would be expected to be well engineered, monitored and maintained for a substantial period of time. Bagchi ${ }^{12}$ suggested that aftercare of a typical modern landfill might take place for up to 40-50 years following closure, with monitoring of leachate, groundwater and gas generation required at regular intervals. However, there is uncertainty over what will happen to a landfill in the very long term, especially as some contaminants may persist for centuries. ${ }^{13}$ There is also a current problem in which older landfills are not properly recorded, and so their location and contents are not known. The EU Landfill Directive now requires hazardous wastes sent to landfill to be pre-treated, in order to reduce their quantity or hazardous nature, facilitate their handling or enhance their recovery, which is expected to improve the long-term performance of landfills.

A final consideration is that in any situation where contamination is contained, be it in a well-engineered modern landfill or on site, the system will ordinarily be suitable for the conditions prevalent at the time of remediation. However, in the long term, conditions may alter because of natural changes such as variation in groundwater levels or perhaps effects due to climate change. If the technical/environmental sustainability of remediation projects is to be properly assessed then attention needs to be paid to the wide range of long-term impacts.

\section{COMBINED MCA AND DIA FINDINGS}

A summary of the combined findings from both the MCA, detailed in Part $1,{ }^{1}$ and DIA in terms of the comparative performance of the five remediation techniques is presented in Table 7, in which the projects are ranked between 1 (best) and 5 (worst) in each area. Some of the areas considered in the DIA are included in subcategories within the MCA, and the results from the DIA were therefore used in developing the scores for those subcategories in the MCA. However, the score for the relevant MCA category is not necessarily the same, as the MCA categories take into account the impact of a number of 


\begin{tabular}{|c|c|c|c|c|c|}
\hline & $\mathrm{S} / \mathrm{S}$ & $\begin{array}{c}\text { Soil } \\
\text { washing }\end{array}$ & Bioremediation & $\begin{array}{l}\text { Cover } \\
\text { system }\end{array}$ & Landfilling \\
\hline \multicolumn{6}{|l|}{$\begin{array}{l}\text { Criterion I: } \\
\text { MCA categories: }\end{array}$} \\
\hline Human health/safety & 1 & 4 & 3 & 2 & 5 \\
\hline Local environment & 2 & 5 & 3 & I & 4 \\
\hline Stakeholder concern & 3 & 4 & 2 & 1 & 5 \\
\hline Site use & 4 & 3 & 2 & 1 & 5 \\
\hline Global environment & 2 & 3 & 5 & 1 & 4 \\
\hline Total MCA & 2 & 4 & 3 & 1 & 5 \\
\hline Criterion 2: & & & & & \\
\hline $\begin{array}{l}\text { Risk to human health } \\
\text { Criterion 3: }\end{array}$ & 5 & 4 & 1 & 2 & 3 \\
\hline Global warming emissions impact & 5 & 2 & 3 & 1 & 4 \\
\hline Other emissions impacts & 2 & 4 & 3 & I & 5 \\
\hline Road travel & I & 3 & 2 & 4 & 5 \\
\hline Material use & I & 4 & 3 & 2 & 5 \\
\hline $\begin{array}{l}\text { Future site reusability } \\
\text { Other parameters }\end{array}$ & 2 & 5 & 3 & 4 & I \\
\hline Energy use & 2 & 3 & 4 & 1 & 5 \\
\hline Noise & I & 3 & 4 & 5 & 2 \\
\hline HGV movements & 3 & 4 & 1 & 2 & 5 \\
\hline Length of site works & 4 & 2 & 3 & 1 & 5 \\
\hline Impact on other sites & I & 4 & 3 & 2 & 5 \\
\hline Remediation location & I & 4 & 3 & 2 & 5 \\
\hline Break in pollutant linkage & 2 & 2 & I & 2 & 2 \\
\hline
\end{tabular}

performance between different remediation strategy options that could aid future decision-makers in selecting the most sustainable remediation strategy on contaminated sites.

\section{DISCUSSION OF THE ASSESSMENT METHODOLOGY}

The two assessment techniques used in this twopart analysis-multi-criteria analysis (MCA) and detailed impact analysis (DIA)-have been combined to provide both an overall picture and a detailed investigation of the individual impacts of the technical/environmental sustainability of remediation. The two techniques were chosen to complement one another, as the MCA gives an overall picture and can include qualitative information, whereas the DIA permits a focus upon specific

subcategories collectively. An example of this is a comparison between the ranking of the risk to human health from the MCA (Criterion 1), in which for example the in situ S/S project is ranked comparatively best, and the DIA (Criterion 2), in which the same project is ranked comparatively worst.

The table shows the specific areas in which each remediation project performed relatively positively or negatively compared with the other four, and for each project it highlights the areas with most relative negative impacts. These areas may need to be addressed in future remediation projects if sustainability is included in the decision-making process.

It should be noted that, as the actual data in the previous sections show, in some cases the differences between the different projects are quite small. Hence this type of ranking does not take into account the level of differences between the different rankings. In addition, certain effects may arise that are not scaled by using the functional unit applied, and so may skew the results presented here. For example, the duration of site works presented in Table 6 showed that the two smallest projects (S/S and excavation and disposal to landfill) had the longest durations per t of soil remediated, which may be, at least in part, a result of factors such as mobilisation and demobilisation on site that are not linearly related to the volume of remediated material.

Based on the methodology employed in the MCA, the cover system project was found to perform best and the landfilling project worst. Many elements of the DIA have provided evidence as to why this is the case. The work presented in both papers shows how both assessment techniques can be combined to develop a meaningful matrix of relative areas in detail but requires quantitative data. This therefore allows consideration of the four criteria discussed in the introduction. There are also disadvantages, however. The use of qualitative information in the MCA leads to the introduction of subjectivity, both in scoring and in weighting. It is therefore important to be able to justify why particular numbers were used, as is done in Part 1. In the analysis here, qualitative data were based on available information, although in a complete application of this methodology considerable effort may be required to ensure that scores and weightings are developed as accurately as possible. The DIA is particularly data-intensive, as a considerable number of individual parameters should be considered in great depth. Availability of data was a particular problem in the analysis presented in these papers.

\section{CONCLUSIONS}

The detailed impact assessment performed on the five remediation projects considered here resulted in a number of findings. The disposal to landfill project, as expected, was generally ranked the worst in all the comparisons made except for risk to human health, emissions, future site usability, noise and break in pollutant linkage. Since it was included in the assessment as a base for comparison it is excluded from the comparisons below. In terms of risk of contamination to human health, this was significantly reduced in all five projects, although the ex situ bioremediation project was comparatively the most effective and the in situ stabilisation/ solidification the least. In terms of the impacts of bringing about the remediation, the following was concluded for each of the parameters considered (for these five projects only).

(a) Global warming emissions impacts: cover system project best and in situ stabilisation/solidification project worst. 
(b) Other emissions impact: cover system project best and soil washing project worst.

(c) Road travel: in situ stabilisation/solidification project best and cover system project worst.

(d) Use of natural resources: in situ stabilisation/solidification project best and soil washing project worst.

(e) Future site reusability: in situ stabilisation/solidification project best (although this does not take into account future durability of containment) and soil washing project worst.

( $f$ ) Energy use: cover system project best and ex situ bioremediation project worst.

(g) Noise: in situ stabilisation/solidification project best and cover system project worst.

(h) HGV movements: bioremediation project best and soil washing project worst.

(i) Length of site works: cover system project best and in situ stabilisation/solidification project worst.

(j) Impact on other sites: in situ stabilisation/solidification project best and soil washing project worst.

(k) Remediation location: in situ stabilisation/solidification project best and soil washing project worst.

(l) Break in the pollutant linkage: in situ bioremediation project best with all the remaining projects scored equally worst.

It should be noted that the assessment used here is drawn entirely from the assessment of five site-specific projects, and therefore does not necessarily represent an analysis of the generic remediation technologies themselves, although many of the points raised will also apply to these. In terms of durability of the remediation process, the paper highlighted the significant shortage of information that is needed for adequate assessment of this category. Parts 1 and 2 show how the two assessment techniques of multi-criteria analysis and detailed impact assessment have been related, and how they can be combined to develop a meaningful matrix of relative performance between different remediation strategy options that could aid future decision-makers in selecting the most sustainable remediation strategy on contaminated sites. The matrix also shows the range of less favourable sustainability issues for each project that may need to be addressed in future projects if sustainability is included in the decision-making process.

\section{ACKNOWLEDGEMENTS}

The authors gratefully acknowledge the financial support of the UK Engineering and Physical Sciences Research Council (EPSRC) grant GR/S148809/01, through the SUBR:IM (Sustainable Urban Brownfield Regeneration: Integrated Management) research consortium, as well as Delta-Simons Ltd and May Gurney Ltd who provided case study information for the analysis.

\section{REFERENCES}

1. Harbottle M. J., Al-TabbaA A. and Evans C. W. Sustainability of land remediation. Part 1: Overall analysis. Proceedings of the Institution of Civil Engineers, Geotechnical Engineering, 2008, 161, No. 2, 75-92.

2. HeWLETT P. C. (ed.). Lea's Chemistry of Cement and Concrete, 4th edn. Arnold, London, 1998.

3. EnVIronment Agency. The Contaminated Land Exposure Assessment (CLEA) Model: Technical Basis and Algorithms. Environment Agency, Bristol, 2002, CLR10.

4. Environment Agency. CLEA UK. Environment Agency, Bristol, 2005, SCH01005BJPY-E-C.

5. LIPPIAT B. C. Building for Environmental and Economic Sustainability (BEES): Technical Manual and Users Guide. US National Institute of Standards and Technology, Gaithersburg, MD, 2002, NISTIR 6916.

6. Al-TABBAA A. and Boes N. Pilot in situ auger mixing treatment of a contaminated site. Part 4. Performance at 5 years. Proceedings of the Institution of Civil Engineers: Geotechnical Engineering, 2002, 155, No. 3, 187-202.

7. ANTEMIR A., Hills C. D., CAREY P. J., SPEAR J. GARDNER K., BoARDMAN D. I. and Rogers C. D. F. Performance assessment of stabilised/solidified waste-forms: initial results from site characterisation, sampling and testing. Proceedings of the International Conference on Stabilisation/Solidification Treatment and Remediation, Cambridge, UK. Balkema, London, 2005, pp. 133-137.

8. Perera A. S. R., Al-TabbaA A., Reid J. M. and Johnson D. State of Practice Report. Part V: Long-term performance and environmental impact. Proceedings of the International Conference on Stabilisation/Solidification Treatment \& Remediation, Cambridge, UK. Balkema, London, 2005, pp. 437-457.

9. BENSON C. H. Final cover for waste containment systems: a North American perspective. Proceedings of the 17th Conference of Geotechnics of Torino: Control and Management of Subsoil Pollutants. Italian Geotechnical Society, Torino, 1999, 1-32.

10. Muldigan C. N. and Yong R. N. Natural attenuation of contaminated soils. Environment International, 2004, 30, No. 4, 587-601.

11. THOMAS B. R. Possible effects of rising groundwater levels on a gasworks site: a case study from Cardiff Bay, UK. Quarterly Journal of Engineering Geology, 1997, 30, No. 1, 79-93.

12. BAGCHI A. Design, Construction and Monitoring of Landfills. Wiley, New York, 1994.

13. BoZKURT S., MORENo L. and NeRETnIEKS I. Long-term processes in waste deposits. Science of the Total Environment, 2000, 250, No. 1-3, 101-121.

\footnotetext{
What do you think?

To comment on this paper, please email up to 500 words to the editor at journals@ice.org.uk

Proceedings journals rely entirely on contributions sent in by civil engineers and related professionals, academics and students. Papers should be 2000-5000 words long, with adequate illustrations and references. Please visit www.thomastelford.com/journals for author guidelines and further details.
} 